\title{
The Function of Makyong Theater of "Cerita Putri Ratna" on Literature Learning in Senior High School
}

\author{
Anisah Kartika Putri', Suyitno ${ }^{2}$, Muhammad Rohmadi ${ }^{3}$ \\ ${ }^{123}$ Postgraduate Education Indonesian Language FKIP Sebelas Maret University, Indonesia

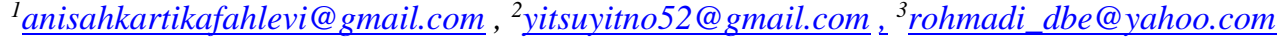

\begin{abstract}
Study this aiming for describe the function from makyong theater is as Learning Literature in high school. This study uses descriptive methods qualitative to describe the phenomena that take place in the present and the past. The use of this type of research describes data with words or sentences that are distinguished according to certain parts of the elements to obtain conclusions. Data from this study are in the form of documents. The document used as a source of data in this study is a video of the performance of the makyong theater and the results of a document review from Malay royal library in the area of North Sumatra. The primary data sources in this study were (a) informants, (b) documents, (c) Makyong Theater videos "Cerita Putri Ratna". While secondary data sources are relevant primary books, international journals, papers, etc. that are needed in the study of theory. Data analysis used is an interactive analysis method. Based on the results of the study there are five main discussions, namely (1) Media Function of Aesthetic Expression, (2) Propaganda function, (3) education function.
\end{abstract}

Keywords : Function Culture; Makyong Theater; Learning Literature

\section{Introduction}

Humans basically have culture and civilization. The creation of a culture is based on thinking, doing, and created by humans, which is based on the guidance of God Almighty. Human culture includes aspects of religious systems, languages, social organizations, technology, education, economics, and the arts. Everything is formed in three forms of culture: ideas or ideas, activities or activities, and objects or artifacts.

Brisling (1990) Culture refers to broad shared ideals, values, formation and use of categories, assumptions about life, and goal-directed activities that become consciously or unconsciously accepted as "right" and "wrong" by people who identify themselves as members of the community. In addition there are also cultural values contained in culture. Cultural values are the highest and most abstract of customs. Cultural values also function as human life guidelines in society, but as a concept, a cultural value that is very general in nature, has a very broad scope, and is usually difficult to explain rationally and realistically. However, precisely because of its general, broad, and not concrete nature, the cultural values in a culture are in the emotional area of the souls of individuals who are concerned citizens and cultures (Koentjaraningrat, 2009).

In Indonesia, especially in North Sumatra, Medan and more precisely in Deli Serdang Regency, there are many forms of art. Starting from traditional arts go to arts that are considered modern that have experienced cultural contact from abroad. Some traditional arts which until now have been extinct and cannot be preserved anymore due to lack of attention from the community of the owner and the relevant government parties. One form of art that exists in Malay culture in the area of North Sumatra, especially in Medan, namely traditional arts called makyong theater arts.

Makyong is one of the heritage of traditional Malay art. Where this art in the performance shows elements of ritual and combines elements of story, dance, singing and music in the performance. In the past, this performing arts lived and developed in several 
places in North Sumatra and Riau region which served as people's entertainment in the coastal countryside. The art of makyong's role has undergone the modernization of its mention to be a "traditional theater" makyong, in essence one of the material filling the treasures of makyong art can be regarded as a vocal theater that brings players together, and shows it with audiences in the same time and place. According to Bandem and Murgiyanto (1996) makyong is a storytelling-like role art that has been popular among Malay people in Malay Peninsula at least since the 17th century AD dialogue on the stage using Malay.

According to the explanation of Tengku Mira Rozanna Sinar (interviewed on December 2019), makyong entitled Putri Ratna, is a form of traditional Malay theater performance art adapted from the work of Tengku Luckman Sinar Basarsyah II, SH where the performance lasts about 1.5 hours accompanied by music, songs, traditional Malay dances. The history of the existence of Makyong theater in North Sumatra, precisely at Galuh Kesultanan in Serdang, where Makyong theater is a "hand" from the journey of Sultan Sulaiman Syariful Alamsyah (Sultan Serdang to V) when visiting Perlis and Kedah in 1898. At that time Tengku Mahmud was the sultan of Regent Kedah presents a set of makyong music equipment complete with para the player. The existence of the Makyong theater from the past until now still exists and remains maintained and developments and changes have been made. Which one in the past, Makyong staging takes place overnight, however after the changes are made and some developments are carried out within Makyong shows are only one and a half hours or two in each story displayed.

Makyong Story is taken from many Hindu and Javanese stories considered popular. One of these stories is the Son of Hindu Raja Gondang that considered to be taken from the Sauvarna Sangkha Jataka Story (The Golden Shell Jataka) is very famous in Cambodia, Siam, and Tibet. Young God Stories and stories Samadaru is probably considered to be taken from Panji romance story from Java like Raden Panji Inu Kertapati story. The stories are in Makyong always show tell about the kingdom, King, Empress, Princess, Crown Prince who fought for achieving his goal with various calamities, suffering miserable must experienced and finally triumphed with the help of third parties such as gods or goddesses or Friend. In the content of the story describes the resistance between good and bad and then ended in a good victory.

Makyong Theater in Sinar Budaya Grup has a variety of story titles like makyong story entitled "Son of Raja Gondang", "The Story of a Young God", "God Samadaru ". "God or Strong King", "Dewa Indra or Indra Dewa", "Raja Panah's Son", "Gading Bertimah", "Raja Tangkai Hati", "Raja Muda Lakleng", "Raja Muda Lembek", "The Great King in the country of Ho Gading ", "Bedara Muda ",and "Putri Ratna ". There are several similarities in the story of makyong in Sinar Culture Group Serdang and in Riau like Megat Sakti, Mr. Puteri Ratna Emas, Gunung Intan, Wak Role of the Forest, but among the same story is the story of Anak Raja Gondang and the story of the Elephant Grandma Dandaru who most important in the performance. This is because before the story of The son of Raja Gondangand the story of the Elephant Grandma Dandaru must perform rituals and serving offerings and grilled chicken for the success of the Makyong show from beginning to end of the show.

Many values contained in in Teater Makyong that can be learned or applied at school, because Malay culture itself is a culture that is very strong in Islamic values and the stories that are created also greatly build the character's value of children because the stories presented contain history from the ancestors. 
Teater Makyong is part of the literary copyright in general which contains noble values and should be transformed to the younger generation, especially to students in schools through learning activities. Through literary learning, including regional literature, students are expected to have care and sensitivity to the surrounding environment.

Stanislavsky (2002) theater aims to create an event and a series of scenes that can appear simultaneously in a community separately because of the natural law that creates each community formed.According to Herman J Waluyo (2008) theater has a broader meaning because it can mean drama, theater, drama actor groups, and can mean that all forms that can be watched are staged in front of many people. In the opinion of Brook (2002) theater rules are the basic element of theater is dialogue, because through this dialogue there is tension and the assumption that two people who disagree with each other is conflict. In the theater will discuss about humans and humanity, life and life, about the relationship between humans with themselves and with other humans, with nature also with God marked through the dialogue used. Osman ( 2014 ) the origin of theater since humans reacted to life and its environment then traditional drama or theater became a part of art that can arouse emotional or motivation in students .

In learning this theater is one of the oral literature should be seen as an important cultural property and placed in the proper position. The story in the Makyong theater can be used in literary learning at school and can be expressed through the learning process of various traditions, customs, culture and history of life in past. From the express and implicit things in the story of the Makyong theater, it can be taken as an alternative solution to the problems that exist today. Therefore, theater can be used by Indonesian language teachers as language learning material and can also be used for literary appreciation learning material which aims to educate children to be more skilled in appreciating ability self especially in field literature .

\section{Research Methods}

This research is a descriptive qualitative research with literature study and is not related to the research site. This research was conducted using a qualitative approach. Sugiyono (2008) argues that qualitative research is a research method based on pospositivism philosophy that is used to examine natural conditions and researchers act as key instruments. This study uses a type of descriptive research that is intended to describe the phenomena that take place in the present and past. The use of this type of research seeks to describe data with words or sentences that are distinguished according to certain parts of the elements to obtain conclusions. While Creswell in his book "Educational Research" or qualitative research is a type of research where researchers are depend on information from objects / participants in: a broad scope, general questions, data collection that consists mostly of words / texts from participants, explain and do analysis of words and conduct research subjectively (Creswell, 2008).

This study uses content analysis (content analysis). This method is one of methods in the social sciences that is used to study and express deeper meanings and dynamic processes behind the content component of a particular literary work or text. Through this analysis, researchers can study the description of the content, characteristics of the message, and the development of the content. If there are documents available, then content analysis can be applied. Krippendorf (1991) stated that a content analysis was a technique for making inferences that can be copied and validated by taking into account the context. The content 
analysis method can see the hidden meaning of a text. Therefore, content analysis is research that is an in-depth discussion of the contents of the document information. Through the use of this method, research seeks to interpret and try to understand the contents of the message and the main ideas contained in the theater being studied.

The data in this study were in the form of documents from the royal Malay library located in North Sumatra. While Data sources according to Moleong (2007) are in the form of primary data sources and secondary data sources. The primary data sources in this study were (a) informants, (b) documents, (c) Teater Makyong videos "Cerita Putri Ratna". While secondary data sources are relevant primary books, international journals, papers, etc. that are needed in the study of theory. Then the procedure for collecting research data is done by documentation or textual studies. Documents can be in the form of writing, images, or someone's monumental works. A textual documentary study or study in the form of a theater text entitled Cerita Putri Ratna by Sinar Budaya Medan Group.

Verification of data in qualitative research is needed to test or check the accuracy of the data collected from the research process. Data verification can be done during the research process. According to Creswell (2010) that verification in qualitative research is an examination of the accuracy of the results of research by applying certain procedures. To verify the data in this study, the researchers used a triangulation strategy. Triangulation is a process of collecting data which is a combination of various sources and existing data collection techniques. Triangulation according to Creswell (2010) is a technique of collecting different data sources by examining the evidence originating from these sources and using it to build coherent themes justification. Next In this study, the data analysis used was an interactive analysis method. Analysis in qualitative research consists of four main components, namely data collection, data reduction, data presentation, and drawing conclusions.

\section{Results and Discussion}

Literary learning is integrated into four language skills (listening, speaking, reading, and writing). The integrated of literature material in the four language skills are no other aim is that students acquire and have the experience to appreciate literature directly. With the experience of appreciating and copying the sense of literature directly, it is expected to foster understanding, appreciation, enjoyment, and appreciation of students for literary work. Thus, appreciation of literature, knowledge and insight of students will increase, awareness and sensitivity of feelings, social and religions will be honed, and there will be appreciation and pride in literature as a repertoire of culture and knowledge.

Literary learning should be directed at developing students' creativity in literature, not only limited to the cognitive knowledge of literature, but at the same time also the productive ability of literature. Drama is one of the educational facilities for personal formation, improving appearance, growing self-confidence and understanding that everyone has advantages and disadvantages, so students will be easier to generate self-confidence, especially when dealing with the public, the psychological burden of speaking, actualizing, and acting in front of many people will naturally be eroded through a series of shared processes that are played in playing drama. During the drama training process it can foster solidarity, solidarity, and cooperation and be able to hone empathy among students. Thus drama words are always associated with theater. As a representation of the existence of 
theater in the community, of course, besides having a function as a place to channel art, theater has a social function. As part of people's lives, theater has a function as a media of aesthetic expression and as a form of propaganda. Among the traditional Makyong theater originating from North Sumatra, the stories presented in Makyong performances have been widely known, because the stories in Makyong are from folktale or inheritance from the palace storyteller. There is no written legacy about Makyong's play. All plays are transmitted through oral tradition. Among Makyong's most famous stories are Putri Ratna Emas, Grandma Gajah and Daru, Cerita Gondang, Wak The Role of the Forest, Gunung Intan, Dewa Muda, Dewa Indra Dewa, Megat Muda, Megat Sakti, Megat Kiwi, Bungsu Sakti, Putri Young Cucumber, Laleng Raja Muda, Raja Tingkai Hati, Raja Dua Sama, Soft King, and Gading Betimbang. Sometimes stories are from the Mahabarata, Ramayana, Panji stories, and Pagarruyung. The last story and material that is mentioned is far different from the original, so that it can only be known from the frame or pattern. An example is the story of the Correlation that comes from Panji Story.

\section{a. Media Function of Aesthetic Expressions}

Theater has a function as a medium or tool to express ideas and ideas that occur in society aesthetically. As a medium of expression that emphasizes more on the ideas of beauty (aesthetic presentation), theater will bring the atmosphere of life that happens in society to actually become a miniature of life flavored with a creative touch and summarized as a spectacle of the life of the community itself. The involvement of the audience in the theater is the most important part of the success of a show. This can happen because the audience will feel feelings of emotion, hatred, anger, likes, fears, or sadness struggling to become one. The more often you see and watch theater or drama, the easier it will be to digest and understand the content of the theater's message. Therefore, you should often watch theater performances, both school and public theater so that your heart, taste and mind are honed in translating a theater performance.

\section{b. Propaganda function}

Theater functions as a propaganda tool which is a part of the performance that combines two forms of theater at once. In this case, actually the function of the theater is maintained but the sidelines of the performance are included in certain programs. For example, government programs, foundation programs or departments related to public services, or political propaganda. This form of theater is adapted to certain situations and conditions according to certain themes. For example, about the socialization of family planning (KB) programs, the dangers of drugs, national discipline, or fuel-saving socialization. The language and invitations in theatrical performances are usually designed in such a way that the audience feels forced or feels patronized by the player.

\section{c. Education function}

Theater directly or indirectly serves as a tool to educate the public. Educating is not only the task of a teacher, lecturer, or other educator. Theater is also able to provide education. In this case, the way to educate is certainly different from a teacher who directly teaches students. In theater, education is usually implicit in the show itself, but is able to arouse the hearts and feelings of the audience. For example, the message of evil deeds will always be defeated by good deeds, good will lead to a beautiful life, evil will lead to chaos 
and destruction, mutual help will strengthen the brotherhood between each other, and so on.

Makyong Theater is part of the literary copyright in general which contains noble values and should be transformed to the younger generation, especially to students in schools through learning activities. Through literary learning, including regional literature, students are expected to have care and sensitivity to the surrounding environment. In theater learning this is one oral literature that needs to be seen as an important cultural wealth and placed in the proper position. The story in Makyong theater can be used in literary learning at school and can be expressed through the learning process of various traditions, customs, culture and history of life in past. From the express and implicit things in the story of Makyong theater, it can be taken as an alternative solution to the problems that exist today. Therefore, theater can be used by Indonesian language teachers as language learning material and can also be used for literary appreciation learning material.

\section{Conclusions and Suggestions}

MakYong is a traditional Malay arts theater whose performances combine various elements of ritual (open land, betabik, facing rebab), and literary art, dance movements, music, all of which are elements of local wisdom values in traditional culture because in art traditional makyong theater is a culture of ancestral heritage that can be learned or applied at school as arousing motivation or self-confidence of students, especially in literary learning, so by appreciating literature, students' knowledge and insight will increase, awareness and sensitivity of feelings, social and religions will honed, and there will be appreciation and pride in literature as a repertoire of culture and knowledge.

\section{References}

Bandem, I Made dan Sal Murgiyanto. 1996. Teater Daerah Indonesia. Yogyakarta: Kanisius.

Brisling, Richard. 1990. Translation, Application and Research. New York: Oxford University Press.

Creswell, J. W. 2010. Research design: pendekatan kualitatif, kuantitatif, dan mixed. Yogjakarta: PT Pustaka Pelajar.

Herman J. Waluyo. 2008. Drama, Teori dan Pengajarannya. Yogyakarta: PT Hanindita Graha. Koentjaraningrat. 2009. Pengantar Ilmu Antropologi. Jakarta: Rineka Cipta.

Krippendorf, Klaus. 1991. Analisis Isi: Pengantar Teori dan Metodenya. Jakarta: Rajawali Press.

Moleong, Lexy J. 2007. Metodologi Penelitian Kualitatif. Published:PT Remaja Rosdakarya. Offset, Bandung.

Osman, Silvia. 2014. About Education through Theater and Cultural Resistance. Procedi Social and Behavioral Sciences (116) 2235 - 2238.

Sugiyono. 2008. Memahami Penelitian Kualitatif. Bandung: Alfabeta. 